\title{
In vitro THROMBOLYTIC POTENTIAL OF BIOACTIVE COMPOUNDS FROM MARINE Streptomyces sp. VITJS4
}

\author{
POTENCIAL TROMBOLÍTICO IN VITRO DE COMPOSTOS BIOATIVOS DE Streptomyces \\ MARINHOS sp. VITJS4
}

\author{
S. Jemimah NAINE; C. Subathra DEVI; Mohanasrinivasan. V \\ School of Biosciences and Technology, VIT University, Vellore,Tamil Nadu, India. csubathradevi@vit.ac.in
}

\begin{abstract}
The most practical approach to reduce morbidity and mortality of coronary heart disease (CHD) is to delay the process of thrombus by usage of clot-dissolving agents. The necessities of such safer compounds are to be critically examined for thrombolytic activity especially, from marine sources. Thrombolytic agents have been investigated as a possible treatment for thrombus. The aim of this study was to investigate the in vitro thrombolytic potential of Streptomyces sp.VITJS4 (NCIM No. 5574); (ACC No: JQ234978.1) active compounds. The fibrin degradation revealed a clear transparent zone of clearance with $500 \mu \mathrm{g} / \mathrm{mL}$ concentration showing $24 \mathrm{~mm}$ hydrolysis. The thrombolytic effect of Streptomyces sp.VITJS4 compounds was also demonstrated in vitro clot lysis assay where The percent of thrombolysis by the crude extract showed $90 \pm 1.7 \%$ at the concentration of $1000 \mu \mathrm{g} / \mathrm{mL}$, whereas percent of thrombolysis by streptokinase was found $100 \pm 00 \% \%$. The bioactive compounds were further studied for spectrophotometric analysis. The UV-VIS profile showed different peaks ranging from 400-700 $\mathrm{nm}$ with different absorption respectively. The data confirmed the presence of both analogues with absorption maxima at 210 and $310 \mathrm{~nm}$. A sensitive method using LC-MS technique was optimized for the separation and identification of bioactive metabolites which was indicated by the fingerprints. The results of the LC-MS analysis provided different peaks determining the presence of compounds with different therapeutic activities. The current study refers the bioactive compound as impressive thrombolytic agent for further laboratory study. Further studies should be conducted to ensure the efficacy and safety of different concentration of bioactive compounds for drug development. Hence the results reported perhaps useful for the discovery of novel thrombolytic drugs from marine origin.
\end{abstract}

KEYWORDS: Bioactive compounds. Clot buster. Marine actinomycetes. Streptomyces sp VITJS4. thrombolytic activity.

\section{INTRODUCTION}

Cardiovascular diseases [CVDs] are caused by intravascular thrombosis. CVDs are the leading cause of death throughout the world. According to a factsheet released by World Health Organization [WHO], about 17.5 million people died from CVDs in 2005 representing $29 \%$ of all global deaths. WHO has recently predicted that the situation will be further worse with passage of time; by 2030, about 23.6 million people will die from CVDs every year (WHO 2011). The major cause of blood clotting disorders leads to various medical health issues. Thrombosis, which is one of the major causes for cerebral and myocardial infarction due to blood clots (HOLDEN 1990). However the former type of thrombolytic agents that includes tissue type plasminogen activator [t-PA], urokinase and streptokinase, nattokinase and lumbrokinase are popular in clinical practice for the treatment of intravascular thrombosis. Despite their widespread clinical use, they induce hemorrhagic side effects, have short half-life in the body, and are also relatively expensive (HERNANDEZ; MARRERO 2005). There are many advances in medical science in the twentieth century, few have been as pervasive as those made in the field of thrombolytic therapy and have more advantage over the synthetic drugs. Therefore, the search for safer and more economical thrombolytic agents from various sources has been receiving huge attention. To date, many thrombolytic agents have been identified and characterized from different sources including bacteria, actinomycetes, fungi and algae (CHANG et al. 2005). Actinomycetes are a special group of microorganisms, which have been demonstrated to be excellent producers of bioactive and structurally novel metabolites (NAINE et al. 2014; BERDY et al.2005; He et al. 2010; KAVITHA et al. 2010). Among them, only a few have been reported from the genera Streptomyces. The distinct class of secondary metabolites obtained from actinomycete bacteria has enough potential, as well as scope for fibrinolytic activities. Streptomyces $\mathrm{sp}$. VITJS4 strain crude extract isolated from the marine environment in South East coast of India,Puducherry, Thavalakuppam showed better efficacy towards larvicidal and repellent activity against malarial and filarial vectors (JEMIMAH; SUBATHRA DEVI, 2014). In continuation, the present study is first of its kind in analyzing the thrombolytic potential using VITJS4 crude extract. 
Therefore, it is necessary to search for novel thrombolytic agents and there is still scope to search new agents which overcome these drawbacks. Hence the present study was designed to investigate the thrombolytic activity of bioactive compounds from marine Streptomyces sp. VITJS4.

\section{MATERIAL AND METHODS}

\section{Chemicals}

Modified nutrient agar base, Blood agar were purchased from HiMedia laboratories (Mumbai, India). Standard streptokinase, thrombin, fibrinogen were obtained from Sigma Aldrich (Bangalore, India). $\mathrm{NaCl}$, Methanol, ethyl acetate, EDTA, Tris were from Sisco research laboratories (SRL, Mumbai, India).

\section{Production of bioactive compound}

The inoculum of Streptomyces sp. VITJS4 (NCIM No. 5574); (ACC No: JQ234978.1) was prepared on starch casein broth at a seed concentration of $100 \mathrm{~mL}$ in a $250 \mathrm{~mL}$ Erlenmeyer flask at an incubation period of 7 days at room temperature, and the medium was adjusted to $\mathrm{pH}$ 7.2. The culture filtrate was centrifuged at 10000 rpm to get a clear solution, and filter sterilized. The final filtrate was mixed with ethyl acetate $(2: 1)$ in a separating funnel to extract the bioactive compounds. After removing the lower aqueous phase, the upper solvent phase was concentrated to obtain crude extract. This crude extract was used for further screening (REMYA et al., 1994).

\section{Fibrin degradation}

$10 \mathrm{~mL}$ of agarose was dissolved to a concentration of $1.5 \%$ in phosphate buffer $(0.005 \mathrm{M}, \mathrm{pH}$ 7.5 in saline) by boiling at $80^{\circ} \mathrm{C}$ and cooled to $40^{\circ} \mathrm{C}$, to which $1 \mathrm{ml}$ of $0.125 \%$ of fibrinogen solution was added and mixed uniformly. Then the mixture is poured on to the sterile plate. $0.2 \mathrm{~mL}$ of $50 \mathrm{U}$ thrombin was added to the fibrin plate and mixed. Series of 2-mm wells were cut in the fibrin plates, Different concentration ranging from $125 \mu \mathrm{g} / \mathrm{mL}, 250 \mu \mathrm{g} / \mathrm{mL}, 500 \mu \mathrm{g} / \mathrm{mL}$ of the active compounds containing each $200 \mu \mathrm{L}$ sample solution was placed on the plate, and the, plates incubated at $37{ }^{\circ} \mathrm{C}$ for $24 \mathrm{~h}$ in a humidified incubator, following which the diameters of zones of lysis surrounding the sample wells. The fibrinolytic activity was quantified by measuring the diameter of the clear (ZHENG et al. 2000).

\section{In vitro thrombolytic activity}

Blood collected from blood bank was transferred in different pre weighed sterile microcentrifuge tube and incubated at $37^{\circ} \mathrm{C}$ for 45 minutes. After clot formation, serum was completely removed (aspirated out without disturbing the clot formed) and each tube having clot was again weighed to determine the clot weight (clot weight $=$ weight of clot containing tube weight of tube alone). Each microcentrifuge tube containing clot was properly labeled and The thrombolytic activity of the active compounds ranging from $62.5 \mu \mathrm{g} / \mathrm{mL}, 125 \mu \mathrm{g} / \mathrm{mL} 250 \mu \mathrm{g} / \mathrm{mL}$ $500 \mu \mathrm{g} / \mathrm{mL}, 1000 \mu \mathrm{g} / \mathrm{mL}$ were determined. Water was also added to one of the tubes containing clot and this serves as a negative thrombolytic control. All the tubes were then incubated at $37^{\circ} \mathrm{C}$ for 90 minutes and observed for clot lysis. After incubation, fluid obtained was removed and tubes were again weighed to observe the difference in weight after clot disruption. Difference obtained in weight taken before and after clot lysis was expressed as percentage of clot lysis. Streptokinae (Sigma), 10,000 KU was used as positive control in the assay. Difference obtained in weight taken before and after clot lysis was expressed as percentage of clot lysis (KHAN et al. 2011, CHOWDHURY et al. 2011).

\section{LC-MS analysis}

Analysis of small amount of chemicals has become easier and more cost-effective owing to the development of hyphenated chromatographic techniques such as LC-MS. The active compounds were subjected to Liquid Chromatography Mass Spectrum profiling and identified on a 410 Prostar Binary LC with 500 MS IT Photo Diode Array Detectors [PDA], Varian Inc, USA comprising of a Surveyor PlusTM Highperformance liquid chromatography [HPLC] system equipped with a three simultaneous channel PDA detector and a linear trap quadropol mass spectrometer [LTQ] fitted with an electronic spray ionization source. All of these approaches can be applied to determine broad classes of metabolites which are advantageous.

\section{UV analysis}

The active compounds were subjected to UV-visible spectra. The ultraviolet spectroscopy were recorded on Shimadzu 160A, The UV absorption of each sample was read from $200 \mathrm{~nm}$ 400nm and compared against the UV absorption of the control. The screening for significant peaks provided a basis for selection of active compounds for further investigation. 


\section{RESULTS}

In the course of systematic screening, Streptomyces sp VITJS4 isolated from marine saltern, Southern India were subjected to preliminary screening. The fibrinolytic activity of Streptomyces sp VITJS4 active compounds exhibited maximum zone at concentration
$500 \mu \mathrm{g} / \mathrm{mL}$ [24mm], the moderate zone was found at $250 \mu \mathrm{g} / \mathrm{mL}$ [19mm] followed by $125 \mu \mathrm{g} / \mathrm{mL}$ [17mm] . The halo zone on fibrin agarose plate proved the potency of degrading fibrin and its diameter was proportional to the potency of fibrinolytic activity which is expressed in terms of the lytic area [Figure 1].

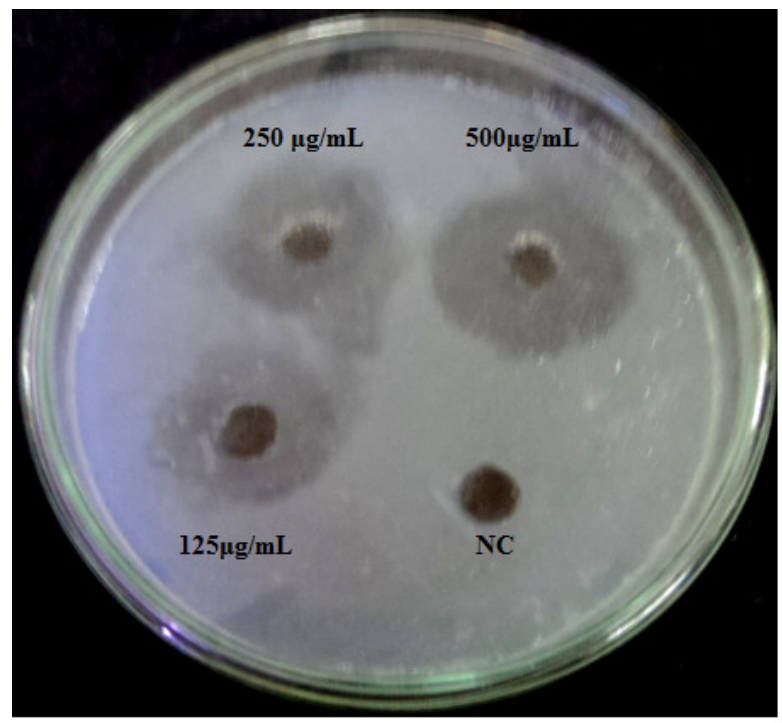

Figure 1. Fibrinolytic activity of Streptomyces spVITJS4 active compounds on fibrin plate

As a part of discovery of cardio protective drugs from natural resources, there is an increasing emphasis for the investigation of thrombolytic activity. Hence the active compounds assessed for clot lysis activity at various time intervals indicated enhanced clot lysis percentage. The results were more promising which exhibited maximum clot lysis in dose dependent manner indicating its thrombolytic potential. The maximum $[90 \pm 0.0 \%]$ clot lysis was observed with $1000 \quad \mu \mathrm{g} / \mathrm{mL}$ concentration in $30 \mathrm{~min}$ of incubation. Desirable result was obtained in the lower concentration of $62.5 \mu \mathrm{g} / \mathrm{mL}$ after $30 \mathrm{~h}$ with [80 $\pm 1.10 \%$ ] clot lysis. On the other hand, Streptokinase SK, a reference standard [10,000 IU] showed a maximum clot lysis effect $[100 \pm 0.0 \%]$ and negative control $[5.32 \pm$ $1.10 \%$ ] at $30 \mathrm{~min}$ of incubation respectively. Streptokinase [positive thrombolytic control] exerts statistically significant thrombolytic activity compared to negative control [normal saline] which exhibited negligible percentage of clot lysis (Figures 2,3;Table 1).

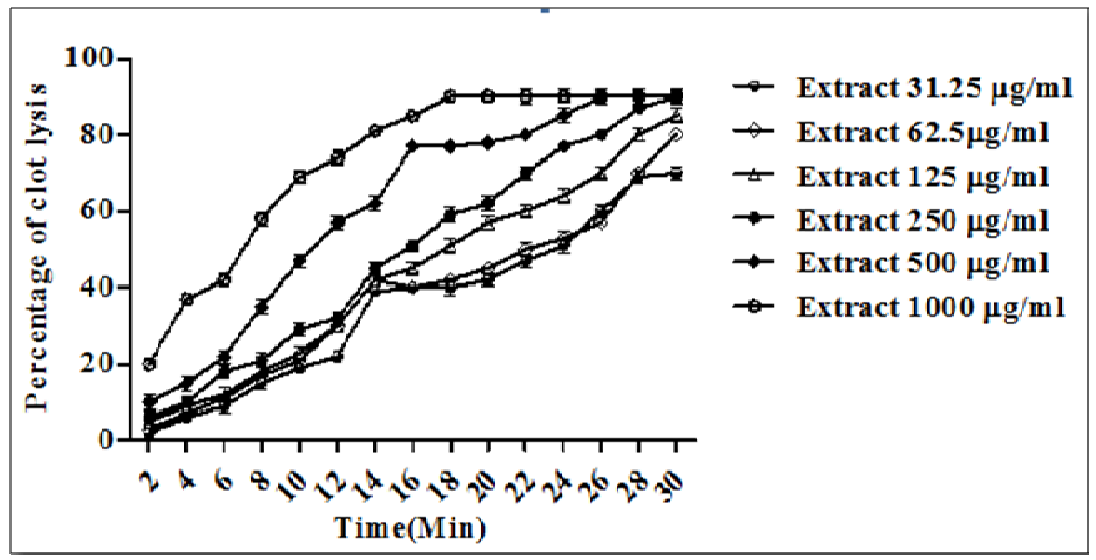

Figure 2. Clot lysis activity of Streptomyces sp VITJS4 active compounds 


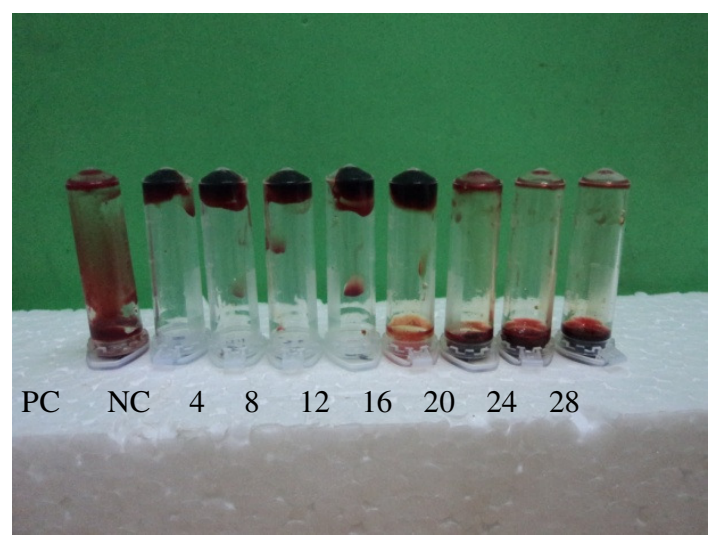

(a)

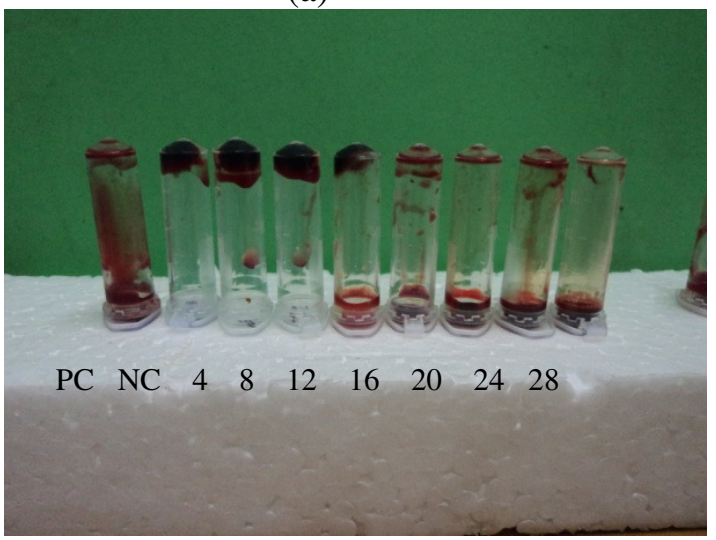

(c)

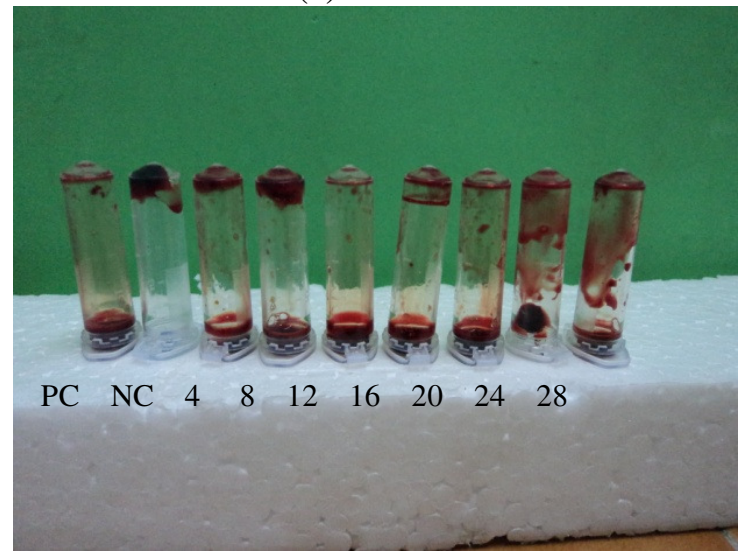

(e)

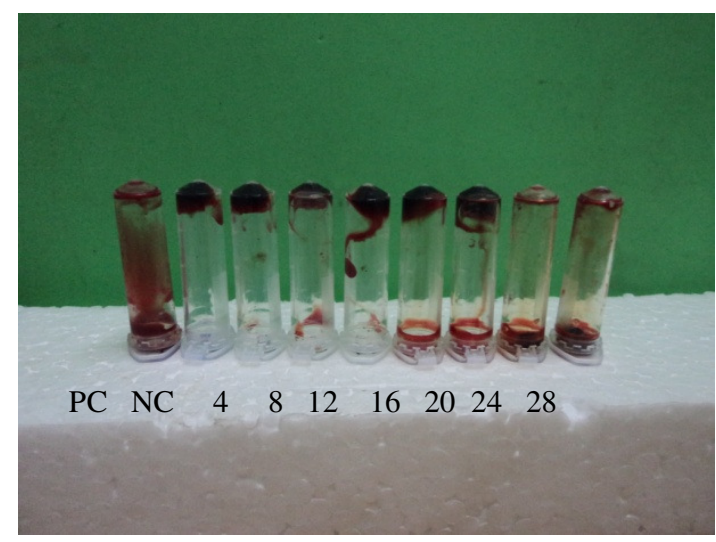

(b)

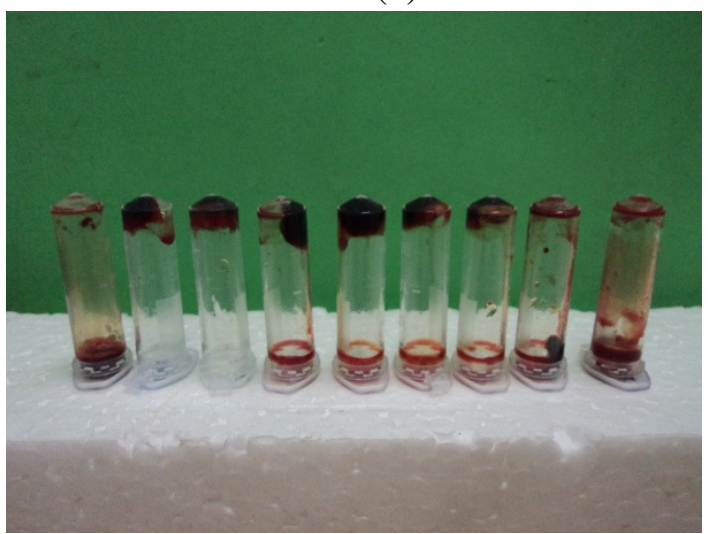

(d)

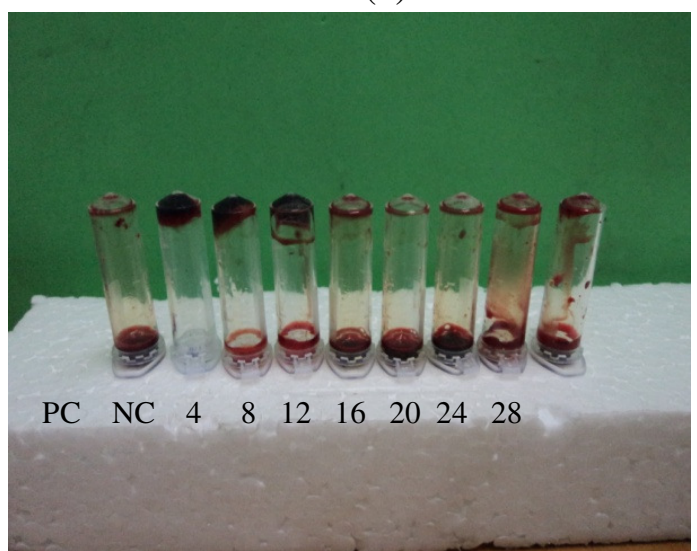

(f)

Figure 3. Effect of active compounds and controls on in vitro clot lysis at different time intervals (a) 31.25 (b) $62.5 \mu \mathrm{g} / \mathrm{mL}$ (c) $125 \mu \mathrm{g} / \mathrm{mL} \quad$ (d) $250 \mu \mathrm{g} / \mathrm{mL} \quad$ (e) $500 \mu \mathrm{g} / \mathrm{mL}$, (f) $1000 \mu \mathrm{g} / \mathrm{mL}$.The pictorial representation is shown for the selected time intervals 
Table 1. Comparative clot lysis analysis for control and active compounds

\section{Extracts/Control}

Positive control Streptokinase(10,000IU)

Negative control Saline $(0.9 \% \mathrm{NaCl})$

Active compounds $(62.5 \mu \mathrm{g} / \mathrm{mL})$

Active compounds $(125 \mu \mathrm{g} / \mathrm{mL})$

Active compounds $(250 \mu \mathrm{g} / \mathrm{mL})$

Active compounds $(500 \mu \mathrm{g} / \mathrm{mL})$

Active compounds $(1000 \mu \mathrm{g} / \mathrm{mL})$
Mean \pm SD (\% Clot lysis)

$100 \pm 0.0 \%$

$5.32 \pm 1.10 \%$

$80 \pm 1.10 \%$

$85 \pm 1.90 \%$

$90 \pm 1.22 \%$

$90 \pm 1.12 \%$

$90 \pm 1.70 \%$

Values are expressed in mean $\pm \mathrm{SD}$

\section{Spectral analysis}

The UV region of the spectrum was obtained using a PDA detector. The data confirm the presence of both analogues showing the peak absorption maxima at $210 \mathrm{~nm}$ [peak 1] and $310 \mathrm{~min}$ [peak 2] (Figure 4).

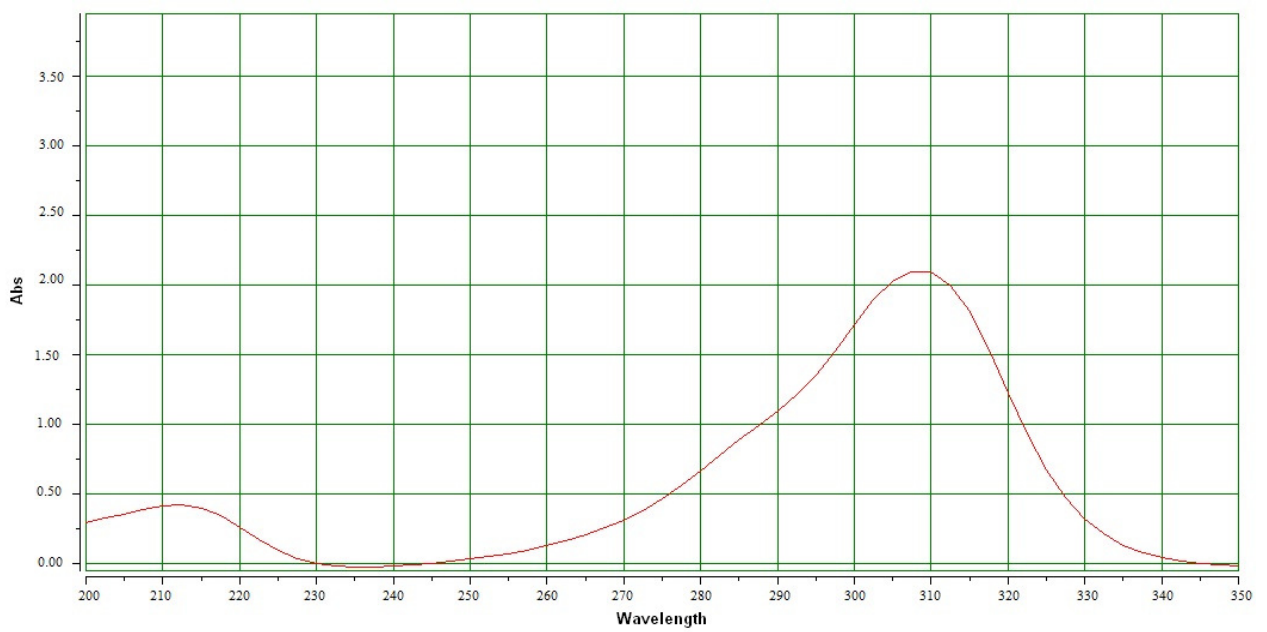

Figure 4. UV spectrum of Streptomyces sp VITJS4 active compounds

The data infers two significant peaks were closer to each other. However these two analogues may share similar structure. Generally chromatographic behaviour and the ultraviolet visible spectrum provide the first clues for the identification of compounds. The structure of compound was determined by interpretation of their spectroscopic data. The molecular formula of single compound showing highest ratio was established $\underline{\mathrm{C}}_{16} \underline{\mathrm{H}}_{22} \underline{\mathrm{O}}_{4}$ based on the peak which is an indicative of compound 1, 2-Benzenedicarboxylic acid, mono[2-ethylhexyl] ester. The LC-MS technique known for its high versatility and sensitivity was incorporated to identify the chemical fingerprint of the metabolites. The metabolite profiles also confirmed the major compound as 1, 2Benzenedicarboxylic acid, mono[2-ethylhexyl] ester indicating its group whose chemical finger prints were closely comparable (Figure 5). 


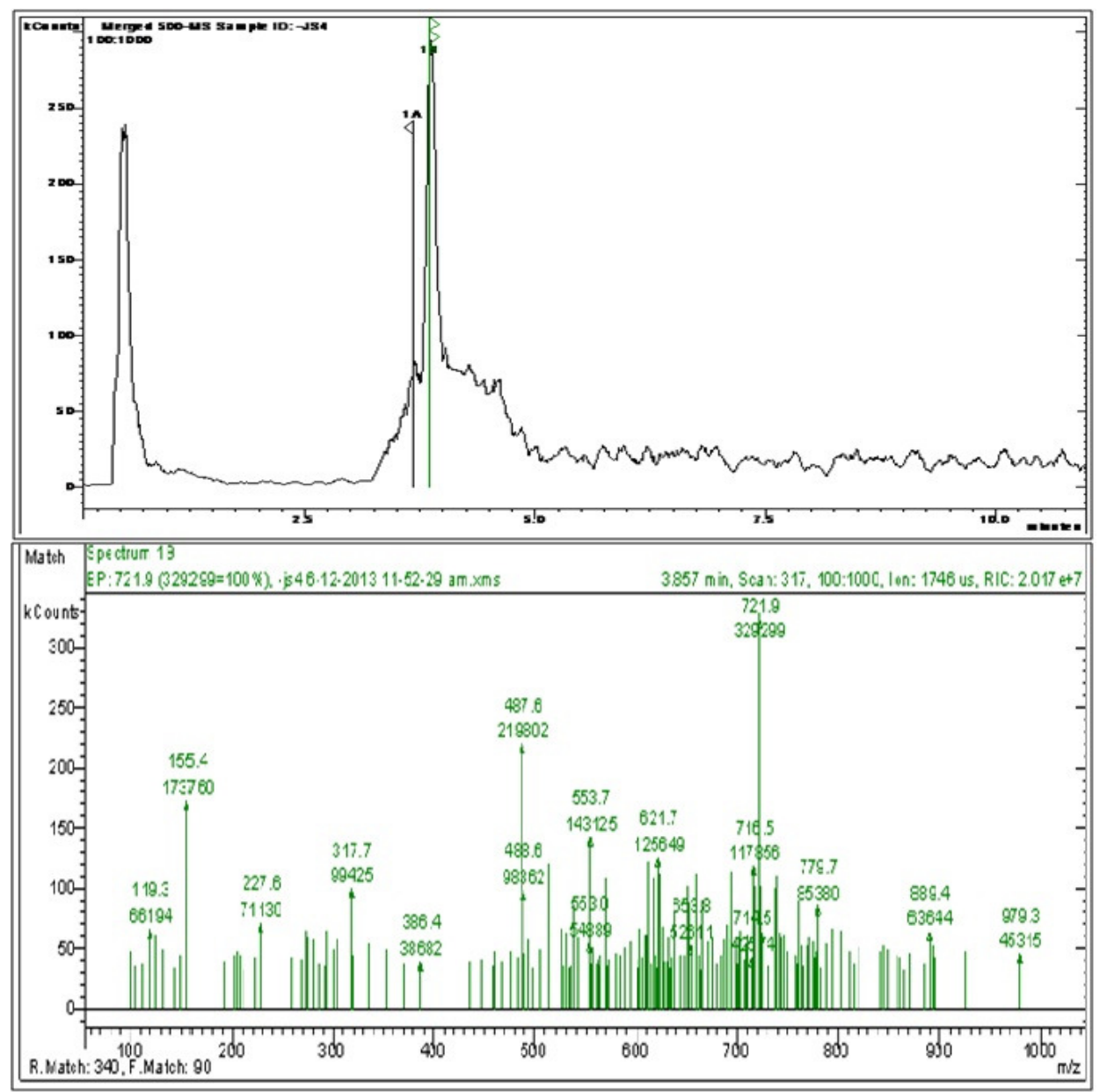

Figure 5. LC-MS chromatogram of Streptomyces sp VITJS4 active compounds

The advance purification will be attained to elucidate the structure of these metabolites by High throughput screening. The results indicate the synergistic effect of the active principles could be useful to combat CVD and perhaps serve as promising new compounds from marine source that warrant further investigation as a candidates for thrombolytic drugs. Hence the results may be useful in the pharmaceutical, biochemical and microbiology industry or academic research in terms of developing alternative control measures and efficient intervention methods.

\section{DISCUSSION}

Actinomycetes residing in a unique marine environment are more important in drug development because they metabolize many rare compounds via unknown pathway. The currently used medications for prevention of thrombosis and thromboembolism are administered by warfarin which is a synthetic drug and has served as the backbone of chronic anticoagulation therapy to prevent thrombotic morbidity. Unfortunately, thrombotic and bleeding complications are observed despite maintenance of therapeutic international normalized ratio [INR] values (NIELSEN et al. 2009). The microbial derived enzymes are known for its potential fibrinolytic activity including nattokinase (MOHANASRINIVASAN et al. 2013; SUMI et al. 1987), lumbrokinase (MIHARA et al. 1991), Streptokinase (VAISHNAVI and SUBATHRA DEVI (2014), Staphylokinase (MOHANASRINIVASAN et al. 2013; SUBATHRA DEVI, 2012), In spite of thrombolytic agent's widespread use, all of them have drawbacks including thermolabile, risk of allergic reactions and large therapeutic doses and bleeding complications (KILLER et al. 2010). Although thrombolytic agents have been isolated from various organisms, the quest for new fibrinolytics has not been stopped yet. Therefore, it is indispensable to screen new thrombolytic agents from diverse sources (MAHAJAN et al. 2012). In the last decade, fibrinolytic enzymes have been identified from various sources including marine actinomycetes. Further, it is believed that sea water, which is saline in nature and chemically closer to the human blood plasma, could provide bio molecules, which could 
have lower or no toxicity or side effects when used for therapeutic applications (SABU et al. 2003). 5(2,4-dimethylbenzyl)pyrrolidin-2-one extracted from marine Streptomyces VITSVK5 sp. has shown to have $60 \%$ lysis with the $\mathrm{EC}_{50}$ value of $288 \mu \mathrm{g} / \mathrm{mL}$ on human erythrocytes (KUMAR et al. 2012). Similar reports on new nystatin-related polyene macrolides from Streptomyces noursei showed haemolytic activity (BRAUTASET et al. 2011). Fibrinolytic agents from Streptomyces omiyaensis (UESUGI et al. 2011) Streptomyces sp. CS684 (SIMKHADA et al. 2010), Streptomyces sp. Y405 (WANG et al. 1999), Streptomyces rimosus (GESHEVA et al. 2009), Streptomyces Violaceoruber and Streptomyces Spiroverticillatus (HABIB et al. 2010) has been reported. A potent fibrinolytic protease (thrombinase) was isolated from marine actinomycetes Streptomyces venezuelae which can be used for the treatment of myocardial infarction (NAVEENA et al. 2012). Actinokinase a new fibrinolytic enzyme reported from thermophilic Streptomyces megasporus. The enzyme is resistant to broad $\mathrm{pH}$ range (CHITTE et al. 2000), Actinokinase enzyme; US patent (CHITTE et al. 2003) and an Indian patent (DEY et al. 2005) have been granted for the process for production of the enzyme using thermophilic Streptomyces megasporus SD5. Streptomyces sp. XZNUM 00004 exhibits a profound fibrinolytic activity (JU et al. 2012). Fibrinolytic enzyme from thermophilic Streptomyces sp. MCMB-379 (CHITTE et al. 2011). Apart from enzymes bioactive compounds also play a vital role against thrombus formation, fibrinolytic compounds isolated from a brown algae, Sargassum fulvellum has been reported with fibrinolytic property (WU et al. 2009). Diketopiperazines, XR330 and XR334 two diketopiperazines, XR334 the novel compound XR330 produced by Streptomyces sp were found with Plasminogen activator inhibitor-1(JUSTIN et al. 1996). Monamidocin from Streptomyces sp. P-2 are fibrinogen receptor antagonist (KAMIYAMA et al. 1995).

Although fibrinolytic enzymes have been extensively studied from Streptomyces, only few reports are available on bioactive compounds possessing these efficient potential. From this study the compound 1, 2-Benzenedicarboxylic acid, mono [2-ethylhexyl] ester identified by spectroscopic data suggest the potential ability which could serve as an interesting tool for thrombolytic therapy. The other bioactive potential of such compound are reported including the anti-tumor, anti- oxidant, antiinflammatory, potent anti-microbial activity (VELMURUGAN et al. 2012). From the results, the study reveals the presence of bioactive molecules from marine actinomycetes perhaps acts as an effective thrombolytic candidate. The results led us to conclude that the natural marine product has important pharmacological substances which can be used for developing new and effective fibrinolytic agents.

\section{CONCLUSIONS}

The drugs used for the cardiovascular diseases are not economical and not accessible to the greater section of the society due to their side effects.

The therapeutic value of marine natural products can substitute and serve as alternatives with fewer side effects.

\section{ACKNOWLEDGEMENTS}

We are greatly indebted to (CSIR) Council of Scientific and Industrial Research for financial support in the form of SRF and Vellore Institute of Technology for the constant encouragement, help and for extending necessary facilities

RESUMO: A abordagem mais prática para reduzir a morbidade e a mortalidade da doença arterial coronariana (CHD, do inglês coronary heart disease) consiste em retardar o processo de trombo através da utilização de agentes de dissolução de coágulos. As necessidades de tais compostos mais seguros devem ser criticamente examinadas para a atividade trombolítica, especialmente de fontes marinhas. Agentes trombolíticos tem sido estudados como um possível tratamento para o trombo. O objetivo deste estudo foi investigar o potencial trombolítico in vitro dos compostos ativos do Streptomyces sp.VITJS4 (NCIM No. 5574); (ACC No: JQ234978.1). A degradação da fibrina revelou um clara zona livre transparente com concentração de $500 \mu \mathrm{g} / \mathrm{mL}$ mostrando uma hidrólise de $24 \mathrm{~mm}$. O efeito trombolítico dos compostos de Streptomyces sp.VITJS4 também foi demonstrado no ensaio in vitro de lise dos coágulos em que a percentagem de trombólise pelo extrato bruto mostrou $90 \pm 1.7 \%$ a uma concentração de $1000 \mu \mathrm{g} / \mathrm{mL}$, enquanto que a percentagem de trombólise pela estreptoquinase foi de $100 \pm 00 \%$. Os compostos bioativos foram estudados posteriormente através da análise espectrofotométrica. O perfil ultra violeta visível (UV-VIS profile, em inglês) mostrou diferentes picos variando entre 400-700 $\mathrm{nm}$ com diferentes absorções respectivamente. Os dados confirmaram a presença de ambos os análogos com absorção máxima em 210 e $300 \mathrm{~nm}$. Um método sensível usando a técnica LC-MS (Liquid 
chromatography-mass spectrometry) foi otimizado para a separação e identificação metabólitos bioativos que foram indicados pelas impressões digitais (?). Os resultados da análise LC-MS forneceram diferentes picos determinando a presença de compostos com diferentes atividades terapêuticas. $\mathrm{O}$ estudo atual refere-se ao composto bioativo como um agente trombolítico impressionante para futuros estudos em laboratório. Estudos futuros devem ser conduzidos para assegurar a eficácia e segurança de diferentes concentrações dos compostos bioativos para o desenvolvimento de drogas. Assim, os resultados reportados talvez sejam úteis para a descoberta de novas drogas trombolíticas de origem marinha. trombolítica.

PALAVRAS CHAVE: Compostos bioativos. Actinomicetos marinhos. Streptomyces sp VITJS4. Atividade

\section{REFERENCES}

ASTRUP, T.; MULLERTZ, S. The fibrin plate method for estimating fibrinolytic activity. Arch Biochem Biophy, v. 40, p. 346-51. 1952. http://dx.doi.org/10.1016/0003-9861(52)90121-5

BRAUTASET, T.; SLETTA, H.; KRISTIN, F.; DEGNES. New nystatin-related antifungal polyene macrolides with altered polyol region generated via biosynthetic engineering of Streptomyces noursei. Appl Env Microbiol, v. 77, n. 18, p. 6636-6643. 2011. http://dx.doi.org/10.1128/AEM.05780-11

CHANG, A. K.; KIM, H. Y.; PARK, J. E. Vibrio vulnificus secretes a broad-specificity metalloprotease capable of interfering with blood homeostasis through prothrombin activation and fibrinolysis. J Bacteriol, v. 187,p. 6909-16. 2005.

CHITTE, R.; DEY, S. Streptomyces megasporus SD5, process for the isolation there of, novel fibrinolytic enzyme prepared there from, process for the production of said enzyme and method of treatment of thrombolytic disorders using said enzyme. US Patent No 6; 638:503.2003.

CHITTE, R. R.; DEY, S. Potent fibrinolytic enzyme from a thermophilic Streptomyces megasporus strain SD5. Lett Appl Microbiol, v. 31, n. 6, p. 405-410.2005

CHITTE, R. R.; DESHMUKH, S. V. Production, purification, and biochemical characterization of a fibrinolytic enzyme from thermophilic Streptomyces sp. MCMB-379. Appl Biochem Biotechnol, v. 165, n. 6, p. 1406-13. 2011. http://dx.doi.org/10.1007/s12010-011-9356-2

DEY, S.; CHITTE, R. R. Indian Patent No. 193435, 2000

GESHEVA, V. Production of fibrinolytic enzyme by Streptomyces rimosus at conditions of nitrogen limitation. J Microbiol Biochem Techechnol, v. 1, n. 1, p. 57-58.2009.

HABIB, S. A.; BODOUBARA, M. I.; ABDEL-MALAK CAMELIA, A. Optimization of fibrinase productivity from Actinomycetes. Egypt J Hosp Med, v. 40, p. 375-388.2010.

HERNANDEZ, L.; MARRERO, M. A. Streptokinase: about of a thrombolytic patented in Cuba. Biotecnol Aplicada, n. 22, p. 191-198.2005.

HOLDEN, R. W. Plasminogen activators: pharmacology and therapy. Radiol, n.174, p. 993-1001.1990.

JEMIMAH NAINE, S and C.SUBATHRA DEVI. Larvicidal and repellent property of marine Streptomyces sp JS4 extracts against dengumalarial and filariasis vectors. Polish J Microbiol, v.63,n.3, p.341-348.2014.

JU, X.; CAO, X.; SUN, Y. Purification and characterization of a fibrinolytic enzyme from Streptomyces sp. XZNUM 00004. World J Microbiol Biotechnol, n. 28, p. 2479-2486. 2012. http://dx.doi.org/10.1007/s11274012-1055-9 
JUSTIN BRYANS.; PETER CHARLTON.; INES CHICARELLI-ROBINSON. Inhibition of Plasminogen Activator Inhibitor-1 Activity by Two Diketopiperazines, XR330 and XR334 Produced by Streptomyces sp. J Antibiot (Tokyo), v. 49, n. 10,p. 1014-21. 1996. http://dx.doi.org/10.7164/antibiotics.49.1014

KAMIYAMA, T.; UMINO,T.; ITEZONO, Y. Production isolation, characterization and structural elucidation. J Antibiot, v. 48, n. 11, p. 1221-5. 1995. http://dx.doi.org/10.7164/antibiotics.48.1221

KHAN, I. N.; HABIB, M. R.; RAHMAN, M. M. Thrombolytic potential of Ocimum sanctum L., Curcuma longa L., Azadirachta indica L. and Anacardium occidentale L. J Basic Clin Phar, v. 2, n. 3, p. 125-127.2011.

KILLER, M.; LADURNER, G.; KUNZ, A. B. Current endovascular treatment of acute stroke and future aspects. Drug Dis Today, v.15, p. 640-647.2010.

MAHAJAN, P. M.; NAYAK, S.; LELE, S. S. Fibrinolytic enzyme from newly isolated marine bacterium Bacillus subtilis ICTF-1: media optimization, purification and characterization. J Biosci Bioeng, v. 113, p. 307-314.2012.

MALAGOLI, A. Full-length protocol to test hemolytic activity of palytoxin on human erythrocytes D. Invert Sur J, v.4, p. 92-94. 2007.

MOHANASRINIVASAN, V.; SUBATHRADEVI, C.; BISWAS, R. Enhanced production of nattokinase from UV mutated Bacillus sp. Bang J Phar, v. 8, n. 2, p. 110-115.2013.

MOHANASRINIVASAN, V.; SUBATHRADEVI, C.; SAHA, A. Screening for Staphylokinase producing Staphylococcus spp. from bovine milk sample. Int J Phar Pharm sci, v. 5, n. 2, p. 601-604.2013.

Naine, J. S.; Nasimunislam, N.; Vaishnavi, B.; Subatharadevi, C. Isolation of soil actinomycetes inhabiting amirithi forest for the potential source of bioactive compounds. Asian J Pharm Clin Res, v. 5, n. 4, p. 189192.2012.

NAVEENA, P.; SAKTHISELVAN, P.; ELAIYARAJU, P. Ultrasound induced production of thrombinase by marine actinomycetes: Kinetic and optimization studies. Biochem Eng J, v. 61, p. 34-42 .2012.

NIELSEN, V. G.; KIRKLIN, J. K.; HOLMAN, W. L. Clot lifespan model analysis of the effects of warfarin on thrombus growth and fibrinolysis: role of contact protein and tissue factor initiation. ASAIO J, v. 55, n. 1, p. 33-40.2009.

SABU, S. Sources, properties and application of microbial therapeutic enzymes. Ind J Biotechnol, v. 2, p. 334341. 2003.

SAURAV, K.; KANNABIRAN, K. Cytotoxicity and antioxidant activity of 5-(2,4-dimethylbenzyl)pyrrolidin2-one extracted from marine Streptomyces VITSVK5 sp. Saudi J Biol Sci, v. 19, n. 1, p. 81-6.2012.

SIMKHADA, J. R.; MANDER, P.; CHO, S. S. A novel fibrinolytic protease from Streptomyces sp. CS684. Process Biochem, v. 45, n. 1, p. 88-93.2010.

SUMI, H.; HAMADA, H.; TSUSHIMA,H. A. Novel fibrinolytic enzyme (nattokinase) in the vegetable cheese Natto: a typical and popular soybean food in the Japanese diet. Experientia, v. 43, p. 1110-1111 .1987.

UESUGI, Y.; USUKI, H.; IWABUCHI, M. Highly potent fibrinolytic serine protease from Streptomyces. Enzyme Microbial Technol, v. 48, p. 7-12.2011.

VAISHNAVI, B.; SUBATHRA DEVI, C. In vitro thrombolytic activity of purified streptokinase extracted from Streptococcus equinus VIT_VB2 isolated from bovine milk. J Thromb Thrombol, DOI 10.1007/s11239-014-1093-2.2014. 
VELMURUGAN, S.; BABU, M. M.; PUNITHA, S. M. J. Screening and characterization of antiviral compounds from Psidium guajava linn. Root bark against white spot syndrome virus. Indian J Nat Prod Res, v. 3, p. 208-214, 2012.

WANG, J.; WANG, M.; WANG, Y. Purification and characterization of a novel fibrinolytic enzyme from Streptomyce $s$ sp. Chinese J Biotechnol, v. 15, p. 83-9

WORLD HEALTH ORGANIZATION. Cardiovascular diseases, http://www.who.int/cardiovascular diseases/en/.2011.

WU, W.; HASUMI, K.; PENG, H. Fibrinolytic compounds isolated from a brown Alga, Sargassum fulvellum. Mar Drugs, v. 7, p. 85-94.2009.

ZHENG, Y. B.; LU, F. P.; DU, L. X. Determination of the activity of fibrinolytic enzyme produced by Rhizopus chinesis sp. Amino Acids Biotic Res, v. 22, n. 1, p. 45-47.2000. 